Jamie Levin* and Dan Miodownik

\title{
The Imperative to Explore the Impact of Disarmament on Peacemaking Efforts and Conflict Recurrence
}

DOI 10.1515/peps-2016-0032

\begin{abstract}
There is today a well-established consensus that belligerents must be disarmed in order to reconstruct shattered states and establish a robust and durable peace in the wake of internal armed conflict. Indeed, nearly every UN peacekeeping intervention since the end of the Cold War has included disarmament provisions in its mandate. Disarmament is guided by the arrestingly simple premise that weapons cause conflict and, therefore, must be eradicated for a civil conflict to end. If the means by which combatants fight are eliminated, it is thought, actors will have little choice but to commit to peace. Disarmament is, therefore, considered a necessary condition for establishing the lasting conditions for peace. To date, however, no systematic quantitative analysis has been undertaken of the practice of disarmament and the causal mechanisms remain underspecified. This paper is a preliminary attempt to fill that gap. In it we outline a series of hypotheses with which to run future statistical analyses on the effects of disarmament programs. The success of negotiations and the durability of peace are, perhaps, the single most salient issues concerning those engaged in conflict termination efforts. We therefore focus the bulk of this paper on a review of the supposed effects of disarmament on negotiating outcomes and war recurrence.
\end{abstract}

Keywords: disarmament, demobilization, conflict resolution, peace agreements

\section{Introduction}

In 1992, the Government of El Salvador and the rebel group Frente Farabundo Marti de Liberacion Nacional, or F.M.L.N., concluded a peace agreement in

*Corresponding author: Dr. Jamie Levin, The Leonard Davis Institute for International Relations, The Hebrew University of Jerusalem, Alfred Davis Building Mount Scopus, Mt. Scopus, Jerusalem 91905, Israel, E-mail: jamie.levin@mail.huji.ac.il

Dan Miodownik: The Hebrew University of Jerusalem, Faculty of Social Sciences, Political Science, Mt. Scopus, Jerusalem, Israel 
Chapultepec Park, an idyll in Mexico City. Brokered by the UN, the Chapultepec Accords, as they came to be known, not only put an end to the more than decade long civil war, they also ushered in a new era of conflict resolution. No longer hamstrung by Cold War rivalries, the UN was free to actively intervene in civil conflicts, which were then surging in number. In fact, more peacekeeping missions have been created since the end of the Cold War than in the previous 45 years combined. And, where previous peacekeeping missions tended to be passive monitoring ceasefires between countries along clearly demarcated boundaries (Dandeker and Gow 1999) - the UN's post Cold War missions have been far more ambitious. These missions, which came to be known as "second generation peacekeeping” (c.f., United Nations 2010), often required that peace be imposed on unwilling combatants while fighting continued to rage within shattered countries where defined boundaries between belligerents do not exist (Doyle and Higgins 1995; Doyle and Sambanis 1999, 2000, 2006; James 1994; O’Neill and Rees 2005; Schnabel 2002).

The disarmament of combatants emerged as a definitive practice of second generation peacekeeping. Indeed, disarmament has been described as a "growth industry" in the post-Cold War era (Muggah 2010, 2). Nearly every UN intervention that has followed Chapultepec has included disarmament provisions in its mandate (Hogbladh 2009). Disarmament is guided by the arrestingly simple premise that weapons are a cause of instability and conflict and, therefore, must be eradicated for a civil war to end. "By removing the means by which civil wars have been prosecuted,” Spear (2002, 141-142) writes, “disarmament is meant to contribute to the security necessary for the successful implementation of civil wear peace agreements." If weapons are eliminated, it is thought, combatants will have little choice but to commit to peace. The monopoly over violence will be restored and shattered states can be reconstructed. Disarmament, is, therefore, considered a necessary condition for peace (c.f., Berdal 1996; DeRouen et al. 2010; Hartzell, Hoddie, and Rothchild 2001; Knight 2004; Muggah 2005; Schulhofer-Wohl and Sambanis 2010; Spear 1999; Walter 1997). Remove the weapons, eliminate the source of instability and conflict, rebuild the state.

While the prevailing literature points to a strong correlation between disarmament and the durability of peace (c.f., Berdal 1996; Brahimi 2000; Cooper 2006; Cousens, Rothchild, and Stedman 2002; Hampson 1996, 1997; Schulhofer-Wohl and Sambanis 2010; Spear 2002; Toft 2009; Wagner 1993), the causal mechanisms at play remain underspecified (c.f., Schulhofer-Wohl and Sambanis 2010). Many recent studies have investigated the impact of disarmament in specific country-cases (c.f., Dzinesa 2007; Knight 2008; Muggah 2004; Özerdem 2002; Paes 2005; Theidon 2007), or have evaluated the role of a 
handful of particular intervening variables on the success or failure of weapons collection programs (c.f., Bouta 2005; Schroeder 2005; Theidon 2009; Willibald 2006 on cash payments; and Farr 2003 on gender; and Williamson 2006 on child soldiers). To date, however, no widespread systematic empirical analysis has been undertaken of the practice of disarmament on the prospects for peace (Schulhofer-Wohl and Sambanis 2010). This ongoing research proposes to fill that gap.

In a 2010 study on the subject of disarmament, Schulhofer-Wohl and Sambanis (2010) catalog a near-definitive list of theoretical claims discussed in the extant literature. We use these as an initial basis for developing hypotheses with which to run future statistical analyses on the effects of disarmament programs. The success of negotiations and the durability of peace are, perhaps, the single most salient issues concerning those engaged in conflict termination efforts. We therefore focus the bulk of this paper on a review of the supposed effects of disarmament on negotiating outcomes and war recurrence.

\section{Hypotheses}

\subsection{Positive effects of disarmament}

Disarmament is generally said to have a positive impact on the intractability of conflict. For example, disarmament is said to help change the underlying structural conditions of conflict, enabling negotiations.

\subsubsection{Disarmament reduces the intractability of conflict}

Several authors note that civil conflict trigger security dilemmas, not dissimilar to those prevailing under conditions of international anarchy (Hartzell and Hoddie 2006; Roe 1999; Snyder and Jervis 1999; Spear 1999; Walter 1997, 2003). When sub-state actors acquire weapons they set in motion a cycle in which future cooperation becomes more difficult. Disarmament is said to help break this cycle making cooperation possible. Spear $(1999,13)$ argues that a failure to disarm belligerents leads to moral hazards. If actors are allowed to retain their weapons, she argues, they will have less of reason to compromise or otherwise commit to peace, leading to more enduring conflicts. By removing the means for further conflict, disarmament leaves actors with little alternative but to sue for peace. In other words, disarmament promotes compromise. 


\subsubsection{Disarmament leads to a more robust peace}

Disarmament is also said to have a positive impact on the long-term durability of peace. In other words, disarmament reduces the likelihood of war recurrence. Both material and psychological reasons are given for this claim. Disarmament is variously said to: remove the means by which wars are fought, (c.f., Muggah 2005; Schulhofer-Wohl and Sambanis 2010), disperse combatants, disrupt their social networks, dismantle their command structures (i.e. the links between commanders and fighters) (c.f., Schulhofer-Wohl and Sambanis 2010, 7-10), delegitimize violence, particularly where there are symbolic public displays of weapons destruction (c.f., Laurence and Meek 1996; Schulhofer-Wohl and Sambanis 2010, 18), all of which should lessen the likelihood of renewed conflict.

\subsubsection{Disarmament leads to reduced rates of post-conflict micro-level insecurity}

Disarmament is also said to have positive secondary effects, in particular in contributing to reduced rates of post-conflict micro-level insecurity. Said differently, disarmament has a positive impact on post-conflict crime rates. Practitioners of disarmament are particularly concerned that the failure to collect weapons in a fulsome or timely fashion risks fuelling crime. Unless disarmament succeeds, they argue, former combatants may use their weapons for crime and/or weapons may fall into the hands of criminals (Berdal 1996; Muggah 2010; Stankovic and Torjesen 2010; Swarbrick 2007; United Nations 2007, 2010).

\subsection{Negative effects of disarmament}

On the other hand the introduction of disarmament provisions is said to act as a break on peace.

\subsubsection{Disarmament reduces or delays the prospects for peace}

The threat of disarmament generates commitment problems, which could delay a peace process or cause cheating. "Neither side can convince the other that they will nobly resist a treaty's temptations or naively fulfill its terms," Walter (1997, 337) writes, "and so, unable to enforce the agreement or survive exploitation, they avoid cooperation and continue to fight." Said differently combatants facing disarmament experience a prisoner's dilemma-like scenario: even if they wish 
to make peace, they cannot trust the other side will do the same. Walter refers to the profound mistrust associated with disarmament provisions as a "security dilemma in reverse." Indeed, she refers to this as "the critical barrier to civil war settlement.”

\subsubsection{Disarmament intensifies conflict}

Some authors suggest that disarmament programs might actually intensify conflict. Hoffman (2004) has shown that disarmament can create incentives for groups to engage in violence. Hoffmann points to examples in which armed groups anticipated that the biggest benefits (i.e. guns-for-cash) would accrue to the most violent. In these cases, violence increased because of disarmament, at least in the short term.

\subsubsection{Disarmament prolongs conflict}

Similarly, Knight and Ozerdem (2004) have suggested that disarmament programs can have the unintended effect of reinforcing ties between combatants, particularly where cantonment is involved. The act of concentrating combatants in remote and generally austere locations for lengthy periods of time can have adverse effects increasing grievances and allowing them time to regroup. Muggah points out that disarmament programs have sometimes enriched combatants and improved their stock of weapons (Muggah 2005; Schulhofer-Wohl and Sambanis 2010, 23). In particular, he suggests caution where disarmament programs allow combatants to exchange unserviceable weapons for cash.

\subsubsection{Disarmament promotes cheating, but allows actors to take risks for peace}

Where an agreement to disarm is reached, actors are often said to cheat, holding back weapons in an effort to remedy the feelings of insecurity outlined above. “Fearing defection,” Lyons (quoted in Spear 2002, 156) writes, “... belligerents hold back weapons... preventing [them] from being completely vulnerable if the settlement falls apart" (see also: Hartzell and Hoddie 2006, 156-157; Knight 2004, 503; Spear 1999, 2002). However, the literature disagrees on the effects of holding back weapons. On the one hand, keeping weapons may provide a "sense of security," allowing actors to take the risks associated with peacemaking (Torjesen and MacFarlane 2007), or "enhance stability" by enabling "either side to punish 
the other for reneging on commitments made under the agreement" (SchulhoferWohl and Sambanis 2010, 21-22). In other words, cheating should help mitigate the security dilemma in reverse and act as insurance against the breakdown of peace and the resumption of violence, allowing actors to engage in risky peacemaking activities.

\subsubsection{Disarmament promotes cheating, undermining confidence in negotiations}

On the other hand, cheating is also said to weaken confidence and lead to mistrust between actors (Axelrod and Hamilton 1981; Oye 1986), which is likely to undermine the prospects for cooperation (Schulhofer-Wohl and Sambanis 2010, 21). The retention of weapons in contravention of a peace agreement is often viewed as evidence that actors have not yet fully committed to the peaceful resolution of their grievances. In other words, cheating should weaken negotiations and undercut the potential for peace to consolidate.

\subsubsection{Disarmament leads to increased insecurity and reduced welfare}

Disarmament is also said to potentially have negative secondary effects, including reduced rates of security and welfare. While there is a "tendency by international organizations," according to Schulhofer-Wohl and Sambanis (2010, 23), “... to see everything related to armed groups as negative" armed groups might provide security in areas that do not otherwise enjoy it. Indeed, armed groups might provide a range of government-like services in areas of limited statehood (c.f., Börzel and Risse 2010). Disarmament may undermine the ability of groups to provide such public goods, particularly where they require the use of force.

\subsection{Intervening variables}

\subsubsection{Third parties are necessary condition for the success of disarmament}

There are two prevailing solutions to the security dilemma in reverse in the literature (Hartzell and Hoddie 2006). Walter $(1997,1999,2003)$ provides what might be described as a neo-realist approach. She argues that belligerents require material guarantees that they will survive defection before they will disarm. Because belligerents cannot provide each other with credible commitments that they will not defect, nor can they rely on the state to enforce such commitments, she sug- 
gests that third parties are a necessary condition for the success of disarmament. Should they make a meaningful commitment to enforcement, and demonstrate it in sufficient strength, third parties, Walter suggests, can provide the credible guarantees that belligerents cannot provide for each other.

\subsubsection{Power-sharing is a necessary conditions for the success of disarmament}

On the other hand, Hartzell and Hoddie (2006) take a neo-liberal approach to the security dilemma in reverse. They argue that combatants will disarm if power is shared in such a way as to guarantee that they won't be disenfranchised from power or subject to arbitrary authority in the future (2003; 2006). Hartzell and Hoddie (2006, 166) view third party guarantees as complimentary, but not necessary for belligerents to disarm. Rather than relying on the force of arms to guarantee an agreement, as Walter proposes, Hartzell and Hoddie (2003, 319) suggest that power sharing in government promotes "a positive sum perception of political interactions" through reciprocity, repeated interaction, and common interests, much the same strategies that are said to make cooperation possible under conditions of international anarchy (c.f., Axelrod and Hamilton 1981; Keohane 1986; Krasner 1983; Oye 1986). Others argue (c.f., Glassmyer and Sambanis 2008) that integrating former combatants into the military similarly allows belligerents to overcome their insecurity.

\section{Discussion}

We have undertaken an initial test of these hypotheses using data derived from the Peace Agreements Dataset (Version 2.0) generated by the Uppsala Conflict Data Program. Our preliminary observations seem to suggest that the inclusion of disarmament provisions improves negotiating outcomes and reduces the rate of war recurrence. We have not found a statistically significant association to support the expectation that DDR provisions in a partial agreement will delay the signing of a full agreement, nor that cheating in the implementation of DDR has an effect on war recurrence. That said, we find some initial support for a positive association between DDR implementation and war termination. We did not find indication that cheating during implementation is related to war recurrence, and contrary to the theoretical expectation we see indications that deploying peacekeepers and promising power sharing tend to increase rather than decrease the rate of cheating on a DDR agreement. While these results are preliminary and require further scrutiny, they suggest that disarmament is an important condition for the cessation of civil conflict. While space does not permit us to test all of the 
relevant hypotheses, we hope that this initial paper may prove fruitful for future researchers investigating the subject.

Acknowledgment: We would like to acknowledge The Azrieli Foundation, The Leonard Davis Institute, and the Truman Institute as well as Lisa Hultman from Uppsala University.

\section{References}

Axelrod, R., Hamilton, W.D., (1981), The Evolution of Cooperation, Science, vol. 211, no. 4489, pp. 1390-1396.

Berdal, M., International Institute for Strategic Studies, (1996), Disarmament and Demobilisation After Civil Wars, Oxford University Press for the International Institute for Strategic Studies.

Börzel, T.A., Risse, T., (2010), Governance without a State: Can it Work?, Regulation \& Governance, vol. 4, no. 2, pp. 113-134.

Bouta, T., (2005), Gender and Disarmament, Demobilization and Reintegration, Clingendael Institute, The Netherlands.

Brahimi, L., (2000), Report of the Panel on United Nations Peace Operations, United Nations, New York.

Cooper, N., (2006), Putting Disarmament Back in the Frame, Review of International Studies, vol. 32, no. 2, pp. 353-376.

Cousens, E.M., Rothchild, D.S., Stedman, S.J., (eds.) (2002), Ending Civil Wars: The Implementation of Peace Agreements, Lynne Rienner, Colorado.

Dandeker, C., Gow, J., (1999), Military Culture and Strategic Peacekeeping, Small Wars \& Insurgencies, vol. 10, no. 2, pp. 58-79.

DeRouen, K., Ferguson, M.J., Norton, S., Park, Y.H., Lea, J., Streat-Bartlett, A., (2010), Civil War Peace Agreement Implementation and State Capacity, Journal of Peace Research, vol. 47, no. 3, pp. 333-346.

Doyle, M.W., Higgins, R., (1995), Second-Generation Peacekeeping, Proceedings of the Annual Meeting (American Society of International Law), The American Society of International Law.

Doyle, M.W., Sambanis, N., (1999), Building Peace: Challenges and Strategies After Civil War, World Bank, Washington.

Doyle, M.W., Sambanis, N., (2000), International Peacebuilding: A Theoretical and Quantitative Analysis, American Political Science Review, vol. 94, no. 4, pp. 779-801.

Doyle, M.W., Sambanis, N., (2006), Making War and Building Peace: United Nations Peace Operations, Princeton University Press, Princeton, NJ.

Dzinesa, G.A., (2007), Postconflict Disarmament, Demobilization, and Reintegration of Former Combatants in Southern Africa, International Studies Perspectives, vol. 8, no. 1, pp. 73-89.

Farr, V., (2003), The Importance of a Gender Perspective to Successful Disarmament, Demobilization and Reintegration Processes, Disarmament Forum, vol. 4, pp. 25-35.

James, A., (1994), Is there a Second Generation of Peacekeeping?, Journal of International Peacekeeping, vol. 1, no. 4, pp. 110-114.

Glassmyer, K., Sambanis, N., (2008), Rebel - Military Integration and Civil War Termination, Journal of Peace Research, vol. 45, no. 3, pp. 365-384. 
Hampson, F.O., (1996), Nurturing Peace: Why Peace Settlements Succeed or Fail. US Institute of Peace Press, Washington DC.

Hampson, F.O., (1997), Can Peacebuilding Work, Cornell International Law Journal, vol. 30, pp. 701.

Hartzell, C., Hoddie, M., (2006), From Anarchy to Security: Comparing Theoretical Approaches to the Process of Disarmament Following Civil War, Contemporary Security Policy, vol. 27, no. 1 , pp. 155-167.

Hartzell, C., Hoddie, M., Rothchild, D., (2001), Stabilizing the Peace After Civil War: An Investigation of some Key Variables, International Organization, vol. 55, no. 01, pp. 183-208.

Hartzell, C., Hoddie, M., (2003), Institutionalizing Peace: Power Sharing and Post-Civil War Conflict Management, American Journal of Political Science, vol. 47, no. 2, pp. 318-332.

Hoffman, D., (2004), The Civilian Target in Sierra Leone and Liberia: Political Power, Military Strategy, and Humanitarian Intervention, African Affairs, vol. 103, no. 411, pp. 211-226.

Hogbladh, S., (2009), UCDP Database Categorical Variables 1989-2008, Uppsala Conflict Data Program, Uppsala University, Sweden.

Keener, S., Heigh, S., da Silva, L.P., Ball, N., (1993), Demobilization and Reintegration of Military Personnel in Africa: The Evidence from Seven Country Case Studies, The World Bank, Africa Regional Series, Washington, DC.

Keohane, R.O., (1986), Neorealism and its Critics, Columbia University Press, New York.

Knight, M., (2004), Guns, Camps and Cash: Disarmament, Demobilization and Reinsertion of Former Combatants in Transitions from War to Peace, Journal of Peace Research, vol. 41, no. 4, pp. 499-516.

Knight, W.A., (2008), Disarmament, Demobilization, and Reintegration and Post-Conflict Peacebuilding in Africa: An Overview, African Security, vol. 1, no. 1, pp. 24-52.

Knight, M., Ozerdem, A., (2004), Guns, Camps and Cash: Disarmament, Demobilisation and Reinsertion of Former Combatants in Transition from War to Peace, Journal of Peace Research, vol. 41, no. 4, pp. 499-516.

Krasner, S.D., (1983), International Regimes, Cornell University Press, New York.

Laurence, E.J., Meek, S., (1996), The New Field of Micro-Disarmament, Addressing the Proliferation and Buildup of Small Arms and Light Weapons. BICC Brief 7, BONN, Germany.

Muggah, R., (2004), The Anatomy of Disarmament, Demobilisation and Reintegration in the Republic of Congo: Analysis, Conflict, Security \& Development, vol. 4, no. 1, pp. 21-37.

Muggah, R., (2005), No Magic Bullet: A Critical Perspective on Disarmament, Demobilization and Reintegration (DDR) and Weapons Reduction in Post-Conflict Contexts, The Round Table, vol. 94, no. 379, pp. 239-252.

Muggah, R., (2010), Innovations, in Disarmament, demobilization and Reintegration Policy and Research, Norwegian Institute of International Affairs, Oslo, Norway.

O’Neill, J.T., Rees, N., (2005), United Nations Peacekeeping in the Post-Cold War Era, Routledge, London, UK.

Oye, K., (1986), Cooperation under Anarchy, Princeton University Press.

Özerdem, A., (2002), Disarmament, Demobilisation and Reintegration of Former Combatants in Afghanistan: Lessons Learned from a Cross-Cultural Perspective, Third World Quarterly, vol. 23, no. 5, pp. 961-975.

Paes, W.-C., (2005), The Challenges of Disarmament, Demobilization and Reintegration in Liberia, International Peacekeeping, vol. 12, no. 2, pp. 253-261.

Posen, B.R., (1993), The Security Dilemma and Ethnic Conflict, Survival, vol. 35, no. 1, pp. 27-47. 
Roe, P., (1999), The Intrastate Security Dilemma: Ethnic Conflict as a Tragedy'?, Journal of Peace Research, vol. 36, no. 2, pp. 183-202.

Schnabel, A., (2002), Post-Conflict Peacebuilding and Second-Generation Preventive Action, International Peacekeeping, vol. 9, no. 2, pp. 7-30.

Schroeder, E., (2005), A Window of Opportunity in the Democratic Republic of the Congo: Incorporating a Gender Perspective in the Disarmament, Demobilization and Reintegration Process, Peace, Conflict \& Development, vol. 6, no. 6, pp. 4.

Schulhofer-Wohl, J., Sambanis, N., (2010), Disarmament, Demobilization, and Reintegration Programs: An Assessment, Folke Bernadotte Academy Research Report, Sweden.

Spear, J., (1999), The Disarmament and Demobilisation of Warring Factions in the Aftermath of Civil Wars: Key Implementation Issues, Civil Wars, vol. 2, no. 2, pp. 1-22.

Spear, J., (2002), Disarmament and Demobilization, in Stedman, S., (ed.), Ending Civil Wars: The Implementation of Peace Agreements, Lynnne Rienner Publishers, Colorado.

Snyder, J., Jervis, R., (1999), Civil War and the Security Dilemma, in Barbara F. Walter and Jack Snyder (eds.), Civil War, Insecurity, and Intervention, Columbia University Press, New York.

Stankovic, T., Torjesen, S., (2010), Fresh Insights on Disarmament, Demobilisation and Reintegration: A Survey for Practitioners, Norwegian Institute of International Affairs (NUPI), Oslo.

Swarbrick, P., (2007), Avoiding disarmament failure: the critical link in DDR, in Small Arms Survey, Geneva Graduate Institute of International Studies, Switzerland.

Theidon, K., (2007), Transitional Subjects: The Disarmament, Demobilization and Reintegration of Former Combatants in Colombia, International Journal of Transitional Justice, vol. 1, no. 1, pp. 66-90.

Theidon, K., (2009), Reconstructing Masculinities: The Disarmament, Demobilization, and Reintegration of Former Combatants in Colombia, Human Rights Quarterly, vol. 31, no. 1, pp. 1-34.

Toft, M.D., (2009), Securing the Peace: The Durable Settlement of Civil Wars. Princeton University Press, Princeton, NJ.

Torjesen, S., MacFarlane, S.N., (2007), R before D: The Case of Post Conflict Reintegration in Tajikistan, Conflict, Security \& Development, vol. 7, no. 2, pp. 311-332.

United Nations, (2007), Integrated Disarmament, Demobilization and Reintegration Standards, New York.

United Nations, (2010), Second Generation Disarmament, Demobilization and Reintegration (DDR) Practices in Peace Operations, United Nations, New York.

Wagner, R.H., (1993), The Causes of Peace, in Licklider, R., (ed.), Stopping the Killing: How Civil Wars End, NYU Press, pp. 235-268.

Walter, B., (1997), The Critical Barrier to Civil War Settlement, International Organization, vol. 51, no. 3, pp. 335-364.

Walter, B., (1999), Designing Transitions from Civil War: Demobilization, Democratization, and Commitments to Peace, International Security, vol. 24, no. 1, pp. 127-155.

Walter, B., (2003), Explaining the Intractability of Territorial Conflict, International Studies Review, vol. 5, no. 4, pp. 137-153.

Williamson, J., (2006), The Disarmament, Demobilization and Reintegration of Child Soldiers: Social and Psychological Transformation in Sierra Leone, Intervention, vol. 4, no. 3, pp. 185-205.

Willibald, S., (2006), Does Money Work? Cash Transfers to Ex-Combatants in Disarmament, Demobilisation and Reintegration Processes, Disasters vol. 30, no. 3, pp. 316-339. 